cemoti $\begin{aligned} & \text { Cahiers d'études sur la Méditerranée } \\ & \text { orientale et le monde turco-iranien }\end{aligned}$

28 | 1999

Turquie-Israël : un siècle d'histoire partagée

\title{
A Triangular Relationship: Turkish Israeli Cooperation and its Implications for Greece
}

Amikam NACHMANI

\section{OpenEdition}

Édition électronique

URL : http://journals.openedition.org/cemoti/594

DOI : $10.4000 /$ cemoti.594

ISSN : $1777-5396$

Éditeur

AFEMOTI

\section{Édition imprimée}

Date de publication : 1 juin 1999

Pagination :

149-162

ISSN : 0764-9878

Référence électronique

Amikam NACHMANI, «A Triangular Relationship: Turkish Israeli Cooperation and its Implications for Greece ", Cahiers d'études sur la Méditerranée orientale et le monde turco-iranien [En ligne], 28 | 1999, mis en ligne le 31 mars 2004, consulté le 08 septembre 2020. URL : http://journals.openedition.org/ cemoti/594; DOI : https://doi.org/10.4000/cemoti.594

Ce document a été généré automatiquement le 8 septembre 2020

Tous droits réservés 


\title{
A Triangular Relationship: Turkish Israeli Cooperation and its Implications for Greece
}

\author{
Amikam NACHMANI
}

\section{RÉSUMÉS}

Pour comprendre la dynamique trilatérale des relations entre Israël, la Turquie et la Grèce et mieux saisir leur complexité, l'auteur les considère sur une durée de cinquante ans, qui correspond à la fondation du jeune État juif. Ce dernier estime que ses rapports étroits avec la Turquie sont une des meilleures réussites de sa politique étrangère. Par ailleurs, la critique portée par les États arabes contre cet état de fait est la preuve même de cette réussite. La Turquie également l'apprécie à sa juste valeur. Il représente en quelque sorte un substitut aux relations assez peu chaleureuses qu'elle entretient avec l'Europe et les Etats-Unis. Quant à la Grèce, elle reste attentive aux réactions du monde arabe, ce qui empêche l'avancement de la coopération entre elle et Israël. 